\title{
Endogenous Opioids Modulate Neuronal Survival in the Developing Avian Ciliary Ganglion
}

\author{
Stephen D. Meriney, ${ }^{\text {a }}$ Maura J. Ford, Daniel Oliva, and Guillermo Pilar \\ Department of Physiology and Neurobiology, The University of Connecticut, Storrs, Connecticut 06269
}

\begin{abstract}
Most studies on the trophic regulation of the normal neuronal competition for survival have focused on interactions between neurons and their target environment. However, it is also likely that trophic modulators are released from premotor inputs onto motoneurons. We have examined the developmental distribution of endogenous enkephalin-like immunoreactivity and the role that these endogenous opioid peptides play in normal neuronal degeneration. During the early portion of the normal cell death period, enkephalin-like immunoreactivity is highest within preganglionic cell bodies in the midbrain and their nerve terminals in the ciliary ganglion. Exogenous daily morphine administration to the chick embryo has previously been shown to delay most of the normal neuronal death in the ciliary ganglion (see Meriney et al., 1985). We hypothesized that opiate receptor activation increases the probability that ciliary ganglion neurons will survive their developmental competition and, further, that the endogenous opioid peptides in the ciliary ganglion normally modulate this competition. However, in our previous report (Meriney et al., 1985), we noted that daily administration of the antagonist naloxone to the chorioallantoic membrane did not significantly alter neuronal survival, as would have been expected if endogenous opioids were involved in regulating cell death. In contrast, in this report we show that three times daily application of naltrexone (a long-lasting opiate antagonist) significantly decreased neuronal survival among the ciliary ganglion cells, and that the surviving cells were not ultrastructurally different than neurons from controls of the same developmental stage. To control for toxic effects of naltrexone, we performed cell counts following naltrexone treatment in another population of cholinergic motoneurons (lumbar spinal motoneurons). In this population of cells, the total number of motoneurons remains unchanged following naltrexone treatment. To test for a specific toxic effect on the neurons of the ciliary ganglion, we generated a dose-response curve for toxicity in vitro and determined that naltrexone was not toxic over concentration
\end{abstract}

\footnotetext{
Received Dec. 11, 1990; revised June 14, 1991; accepted June 19, 1991.

We thank L. Landmesser, D. B. Gray, A. D. Grinnell, and I. Chow for many helpful discussions and critical evaluation of the manuscript; K. Buckley for generously providing the SV2 antibodies; B. Wautlet and L. Lopez for technical assistance; and S. Putnam for editorial assistance. We thank J. Bruses for performing the in vitro ciliary cell toxicity assay. This work was supported by NIH Grant NS10338, NSF Grant BNS 8410581, an MDA postdoctoral fellowship to S.D.M., and The University of Connecticut Research Foundation.

Correspondence should be addressed to Dr. Guillermo Pilar, Department of Physiology and Neurobiology, The University of Connecticut, U-42, 75 North Eagleville Road, Storrs, CT 06269-3042.

a Present address: Jerry Lewis Neuromuscular Research Center, UCLA School of Medicine, Los Angeles, CA 90024

Copyright (C) 1991 Society for Neuroscience $0270-6474 / 91 / 113705-13 \$ 05.00 / 0$
}

ranges that are likely to exist in vivo. It appears, therefore, that a multiple daily antagonist application protocol blocks opiate receptors sufficiently in the ciliary ganglion to decrease an endogenous opiate influence significantly. We tested the possibility that endogenous opioids exert their effect by modifying transmission at peripheral and ganglionic synapses. In the generally accepted hypothesis, paralysis at the peripheral nerve-striated muscle synapse would rescue cells, while paralysis of ganglionic synapses would decrease survival. Iris neuromuscular junctions onto striated muscle cells were not blocked by opioids, but neuromuscular transmission in the smooth muscle of the choroid coat was blocked. Some of the ciliary and choroid ganglionic synapses were blocked, with varying degrees of efficacy at different developmental times. This pattern is not consistent with the above-stated paralysis-dependent hypothesis. We suggest that opioids exert a direct paracrine influence on ciliary ganglion neurons acting through second messengers such as calcium. Opioids are known to block calcium currents in ciliary ganglion neurons, which may prevent a calcium overload, cell damage, and death.

Compctition for survival is a common developmental process that has been characterized in many neuronal populations (see Cowan et al., 1984). Most studies of naturally occurring neuronal death have concentrated on the importance of neurontarget interactions (Levi-Montalcini and Amprino, 1947; Landmesser and Pilar, 1974b; Pittman and Oppenheim, 1979; Pilar et al., 1988a). Several have also pointed to the requirement for central inpuls and synaptic activity onto motoneurons (LeviMontalcini, 1949; Furber et al., 1987; Meriney et al., 1987). In this report, we address the effect of endogenous opioid peptides in the competition for survival.

There are two populations of motoneurons in the ciliary ganglion (ciliary and choroid), which undergo an approximate 50\% reduction in cell number during a defined developmental time period [embryonic day (E) 8-14 or stage (St) 34-40; Landmesser and Pilar, 1974a]. The ciliary and choroid neurons project separately to their respective target tissues: the iris and ciliary body, and the choroid coat (see Landmesser and Pilar, 1978; Meriney and Pilar, 1987; Pilar et al., 1987). We have shown previously that the extent of neuronal death during development in the ciliary ganglion is influenced by synaptic blockade at ganglionic synapses for choroid neurons, and by ganglionic and neuromuscular synapses for ciliary neurons (Meriney et al., 1987). We have also shown that exogenous morphine administration delays most of the normal neuronal death (Meriney et al., 1985). Therefore, since the extent of normal neuronal death is sensitive to alterations in synaptic function, our previous reports are con- 
sistent with the hypothesis that chronic morphine administration could rescue the neurons in the ciliary ganglion from most of their normal death via a synaptic blockade-dependent mechanism. It is generally thought that the target environment may mediate its effects via one or more trophic factors [including perhaps ciliary neurotrophic factor (CNTF); see also end of Discussion]. It is also likely that there are trophic factors that modify neuronal death by acting within the ganglion itself.

The presynaptic terminals onto pigeon ciliary ganglion neurons have been shown to contain enkephalin-like, vasoactive intestinal peptide (VIP)-like, and substance P-like immunoreactivity (Erichsen et al., 1982; Reiner, 1987). Peptides are the most recently discovered class of neuromodulators and neurotransmitters, whose role in the normal functioning of the nervous system is just being realized. Many of these peptides have been shown to influence characteristics of neuronal development, including cell survival, proliferation, and growth (see Handelmann, 1985; Zagon and McLaughlin, 1986; Schmahl et al., 1989; Pincus et al., 1990), acetylcholinesterase activity, and nerve terminal excitability (Haynes and Smith, 1984). While little is known of the ontogeny or actions of VIP in the ciliary ganglion (Reiner, 1987), substance $P$ and enkephalin have been shown to modulate synaptic function (Role, 1984; Dryer and Chiappinelli, 1985; Margiotta and Berg, 1986).

The developmental expression of substance P-like and enkephalin-like immunoreactivity in the ciliary ganglion suggests a role for these peptides in the maturation of these neurons. White et al. (1985) have shown with high pressure liquid chromatography (HPLC) analysis of whole chicken ciliary ganglia that substance $P$ does not increase in the ganglion until after the normal neuronal death period, and therefore may not be relevant in this context. In contrast, they have also shown that opioid peptides increase in the ciliary ganglion during the normal neuronal death period. These observations indicate that endogenous opiate-like peptides are present in the developing ciliary ganglion system and may modulate synaptic transmission during the normal neuronal death period.

In the present article, we continue our study of the role of opioid peptides in the developing chicken ciliary ganglion. First, we quantify the number of terminals containing Leu-enkephalin (LE) and compare this staining with that seen after immunostaining with an antibody against a synaptic vesicle antigen (Buckley and Kelly, 1985) to study the distribution of LE in ganglionic terminals during development. Second, we show that the opiate antagonist naltrexone influences neuronal survival. Third, we demonstrate that although opiates can influence synaptic transmission at some synapses, synaptic blockade is not likely to be the mechanism by which exogenous morphine or endogenous opioid peptides modulate ciliary ganglion neuron survival. Finally, we reveal that during the period of ccll dcath, opioid receptor pharmacology suggests the presence of $\delta$-opioid receptors in the ciliary ganglion. All of these observations implicate endogenous opioids in the regulation of neuronal number during development but argue against the simplest model (ganglionic synaptic activity blockade) for opioid effects on neuronal survival.

A preliminary report of some of these data has appeared in abstract form (Meriney et al., 1985; Gray et al., 1986).

\section{Materials and Methods}

White Leghorn chick embryos were incubated in a forced draft incubator until the desired stage ( $\mathrm{St}$; determined by Hamburger and Hamilton,
1951). Animals were dissected and experiments were performed in a Tyrode's solution of the following composition: $\mathrm{NaCl}, 134 \mathrm{~mm} ; \mathrm{KCl}, 3$ $\mathrm{mM} ; \mathrm{NaHCO}_{3}, 20 \mathrm{~mm} ; \mathrm{CaCl}_{2}, 3 \mathrm{~mm} ; \mathrm{MgCl}_{2}, 1 \mathrm{~mm}$, and glucose, 12 mM. Morphine sulfate was obtained from Mallinckrodt; D-Ala-D-Leuenkephalin (DADLE), naloxone, and naltrexone were obtained from Sigma Chemical Co. (St. Louis, MO). All drugs were either dissolved in isotonic saline for administration to eggs or included in the Tyrode's perfusate bathing the preparation during acute recording experiments.

\section{Ciliary ganglion immunohistochemistry}

White Leghorn chicks or embryos were killed by decapitation, and the ciliary ganglia were dissected from the eyes in Tyrode's solution containing zero calcium. The ganglia were immediately fixed in cold $4 \%$ paraformaldehyde in $0.1 \mathrm{M}$ phosphate buffer (PB) for $3 \mathrm{hr}$ and infiltrated with three changes of $20 \%$ sucrose in PB overnight. Each ganglion was embedded in Tissuc-Tck O.C.T. Compound (Miles, Elkhart, IN) and frozen in 2-methyl butane on dry ice. Serial $10 \mu \mathrm{m}$ frozen sections were cut through an entire ganglion, collected on subbed slides, and dried overnight. The sections were then stained by indirect immunohistochemistry for LE and a synaptic vesicle antigen, SV2, as follows. After rehydration in PB containing $0.3 \%$ Triton X-100 (PBT), the sections were preincubated for $1 \mathrm{hr}$ at room temperature in a blocking solution containing $2 \%$ bovine serum albumin in PBT. The sections were then incubated for $24 \mathrm{hr}$ at $4^{\circ} \mathrm{C}$ in a rabbit antiserum against LE (Immunoclear Corp.), diluted 1:1000 in blocking solution. The sections were washed in PBT and subsequently incubated in goat anti-rabbit fluorescein isothiocyanate (FITC; Sigma), diluted 1:50 in blocking solution, for $1 \mathrm{hr}$ at room temperature. After washing three times in PBT, the sections were incubated with the monoclonal antibody SV2 (kindly provided by K. Buckley, Harvard Medical School), diluted 1:1000, for $1 \mathrm{hr}$ at room temperature. After washing again in PBT, the sections were labeled by incubation with goat anti-mouse rhodamine isothiocyanate (RITC; Sigma), at 1:50, for $1 \mathrm{hr}$ at room temperature. A final rinse in $\mathrm{PB}$ was done before the sections were mounted in Fluoromount $G$ and viewed under epifluorescence with FITC or RITC filters on a Nikon Labophot microscope.

Controls for antigen and method specificity included preadsorption of the primary antisera with $40 \mu \mathrm{M}$ synthetic LE (Sigma), omission of the primary antisera, or incubation with a preimmune rabbit or mouse antiserum instead of the LE or SV2 antisera. No specific staining was seen in any of these controls.

Ciliary and choroid neurons were distinguished in frozen sections by their position in the ganglion and the morphology of their presynaptic terminals. Ciliary neurons showed calyceal terminals after LE and SV2 staining (Fig. 1). Choroid neurons are largely clustered in the ventrobasal region of the ciliary ganglion and had characteristic punctate labeled bouton-like endings (Fig. 1).

The immunostained sections were quantified by counting the number of fluorescently labeled LE- and SV2-containing terminals seen within the same section at $400 \times$ magnification. Every other section was counted, and the total cell counts were also made under phase-contrast optics. The ratios of the \% SV2:cell and \% LE:SV2 were obtained for various stages during and after the normal neuronal death period. No attempt was made to correct for overcounting of split cells in sections since our interest was in relative changes only. This method of quantitation could be done reliably only beginning at $\mathrm{St} 37$. Prior to St 37 , immunoreactivity for both LE and SV2 was often characterized by a widespread punctate network of fibers. Therefore, only qualitative observations are noted prior to St 37 .

\section{Midbrain immunohistochemistry}

White Leghorn chicks or embryos were killed and dissected as described above, except that the entire brain (including midbrain regions) was rapidly removed and immersed in cold $4 \%$ paraformaldehyde in $0.1 \mathrm{M}$ phosphate buffer (PB) for 8-10 hr. Fixed tissue was subsequently washed in $\mathrm{PB}$ for $6 \mathrm{hr}$ (three changes) and embedded in agarose. After polymerization at $4^{\circ} \mathrm{C}$, serial $50-80 \mu \mathrm{m}$ sections were cut on an Oxford vibratome. Sections were collected in cold $\mathrm{PB}$, mounted on slides, and kept at $4^{\circ} \mathrm{C}$ until processed for indirect immunohistochemistry for LE as described above.

\section{Estimations of neuronal number}

Drugs were administered daily, or three times daily, in 50-100 $\mu \mathrm{l}$ volumes to the chorioallantoic membrane of the egg on embryonic days $7-14$ (E7-14) through a window cut in the shell of the egg. In the absence 
of any information on drug absorption, diffusion, or subsequent compartmentalization within the egg, effective concentrations were estimated by simple dilution into an egg volume of $25 \mathrm{ml}$. Using this rough estimation, $20 \mu \mathrm{g}$ of naltrexone is estimated to have an effective concentration in the egg of about $2 \mu \mathrm{M}$. Counts of neurons were made in ciliary ganglia isolated from control and drug-treated embryos. Following overnight fixation in Bouin's solution, ganglia were dehydrated and sectioned in paraffin at $8 \mu \mathrm{m}$. Sections were stained with hematoxylin/ eosin orange, and all neurons in a particular section were counted at $400 \times$ on every fourth section. Only those cells with a distinct nucleolus were counted as neurons, and all counts were corrected for overcounting according to Abercrombie (1946)

\section{Controls for naltrexone toxicity}

In vivo. As one control for the possible toxic effects of three times daily administration of naltrexone, survival of motoneurons in the spinal cord was also determined. Since the normal cell death period for spinal motoneurons occurs earlier than in the ciliary ganglion, two different application protocols were employed. In the first, treatment was initiated at E5 and continued through E14 (a period that spans normal cell death in both the ciliary ganglion and the spinal motoneurons). In the second, treatment only spanned the period of normal cell death in the ciliary ganglion (E7-14).

Additionally, ciliary ganglia from St 40 embryos were processed for electron microscopy as previously described (Pilar and Landmesser, 1976). Briefly, ganglia were removed in oxygenated Tyrode's solution at room temperature and fixed in $1.5 \%$ glutaraldehyde, $1.5 \%$ paraformaldehyde, and $1.5 \%$ acrolein in cacodylate buffer $(\mathrm{pH} \mathrm{7.3)}$ for $5 \mathrm{hr}$. Specimens were postfixed in $2 \%$ osmium tetroxide for $1 \mathrm{hr}$ and dehydrated for embedding in Epon Araldite. Thin sections were cut on an ultramicrotome, mounted on \#200 mesh grids, stained with $2 \%$ uranyl acetate, $1.5 \%$ lead citrate, and viewed with a Phillips 300 electron microscope.

In vitro. Ciliary neuron cultures were derived from 8-d-old chick embryos as previously described (Tuttle et al., 1980). The cells were resuspended in the desired volume of medium (N2 defined media with $1.5 \%$ chick embryo eye extract) and plated ( 3000 cells/well) into polyornithine-coated 96-well microplates. After $2 \mathrm{~d}$ of growth, the cells were fed with the above media plus varying concentrations of naltrexone $(0.02-200 \mu \mathrm{g} / \mathrm{ml})$. After an additional $4 \mathrm{~d}$ of incubation, a colorimetric assay was used to determine the number of living neurons (see Nakanishi et al., 1988, for details). Briefly, $0.5 \mathrm{mg} / \mathrm{ml}$ of 3-(4,5-dimethylthiazol2-yl)-2,5-diphenyltetrazolium bromide was added to each well and incubated for $4 \mathrm{hr}$. The medium was then replaced by dimethyl sulfoxide (DMSO), and the absorbance was read on an automated microplate reader at $540 \mathrm{~nm}$. In control experiments, we determined that the optical density was directly proportional to the number of cells in the range between 1000 and 6000 cells.

\section{Pupillomorphic observations}

To evaluate the effect of morphine on nerve-evoked iris muscle contractions, the ciliary nerves were dissected together with a ring of sclera containing the iris and ciliary body muscles. The lens was removed, and the sclera was pinned to the bottom of a Sylgard chamber. Light was shown from beneath, and pupillary diameters were photographed before or during a high-frequency nerve stimulation with a $35 \mathrm{~mm}$ camera mounted on a dissecting microscope (see Pilar et al., 1987). For observations of chronically treated preparations, $50 \mu \mathrm{M}$ morphine was included in the dissecting and recording solution to ensure that the chronically treated preparation was not washed clean of the morphine present in the egg before observations were made. This morphine concentration is higher than we anticipate in the chronically treated egg; however, since we are not certain of the exact concentration that may be present in the egg, this level was included during the short dissection and recording period to avoid any washout of the chronically treated iris. In addition, it is highly unlikely that this acute exposure to $50 \mu \mathrm{M}$ morphine would influence our assessment of paralysis in the chronically treated iris, since we have never observed such an effect in acutely treated preparations.

\section{Mechanical responses recorded from iris and choroid muscle fibers}

To determine if morphine could influence the neuromuscular activation of the striated muscle cells of the iris or of the smooth muscle cells in
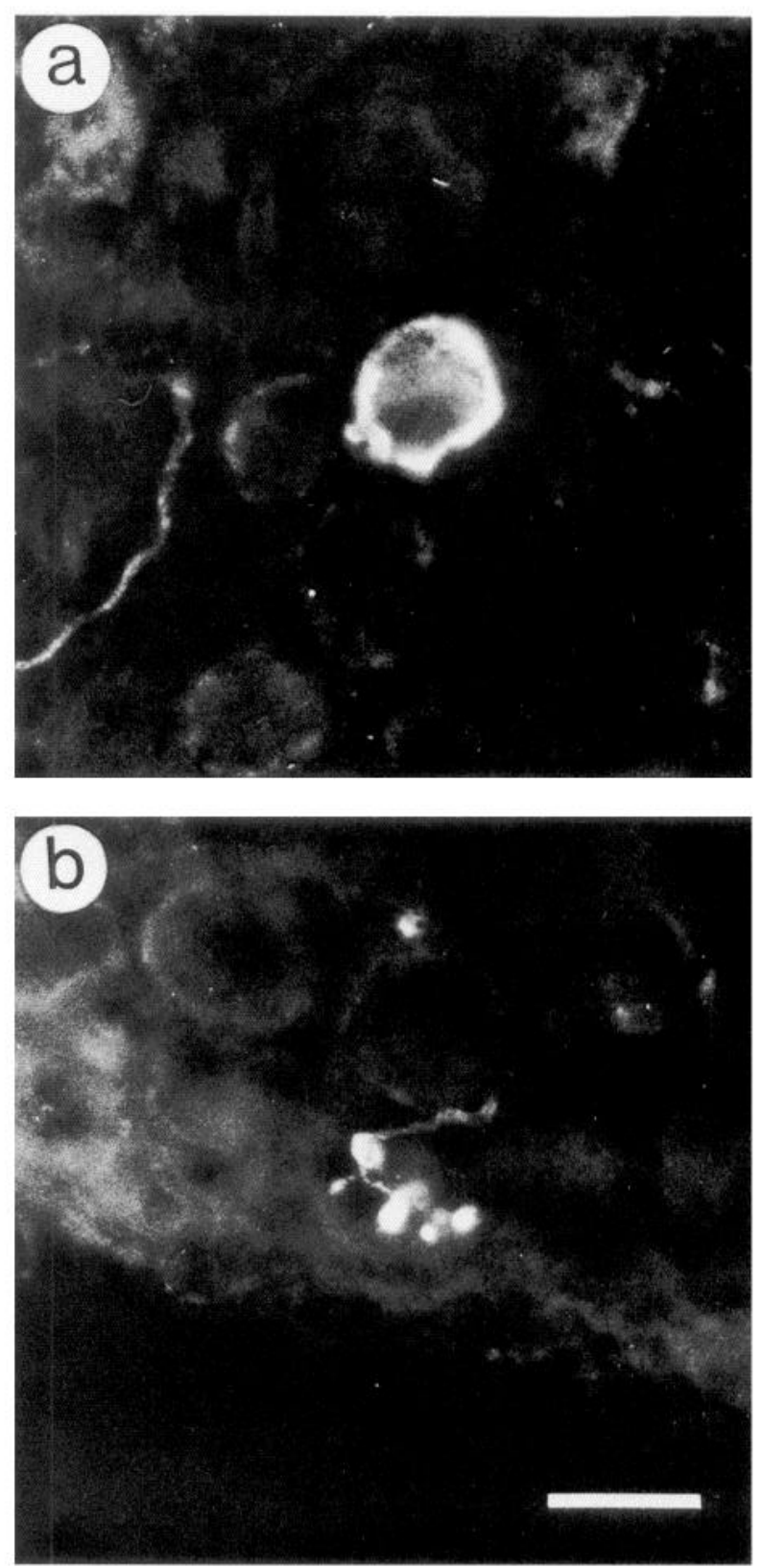

Figure 1. LE-like immunoreactivity present in St 40 ciliary ganglia within calyceal terminals onto ciliary cells $(a)$ and bouton-like terminals onto choroid cells $(b)$. Scale bars, $20 \mu \mathrm{m}$.

the choroid coat, mechanical recordings of muscle tension were performed in the hatchling chick. For recordings of iris contractions, the ciliary ganglion was removed intact with the ciliary nerves and a ring including the ciliary body and the iris muscles. The iris muscle connections to the sclera and ciliary body were cut distal to the entrance of the ciliary nerves such that the iris ring could be attached directly to a strain gauge. The ciliary nerves were stimulated at their emergence from the ciliary ganglion with either single shocks or repetitively at 5 $\mathrm{Hz}$, and contractions were recorded on a strip chart recorder. For recordings of choroid muscle contractions, the ciliary ganglion was surgically removed with the choroid nerves and a large piece of the choroid coat. The distal end of the choroid coat (near the ciliary body insertion into the sclera) was lifted free of the sclera on one side and the retina on the other and tied directly to a strain gauge. The choroid nerves were stimulated $(30 \mathrm{~Hz})$ at their emergence from the ciliary ganglion, and contractions in the choroid coat were monitored on a chart recorder (see Meriney and Pilar, 1987). 
Figure 2. Double labeling of an St 30 ciliary ganglion with antibody to SV2 and LE. $A$, At this early developmental age, there is no detectable SV2 immunoreactivity: No defined synaptic profiles are evident. $B$, LE-like staining is present at a low density and appears as punctate fibers coursing through the ganglion. Scale bar, $20 \mu \mathrm{m}$.
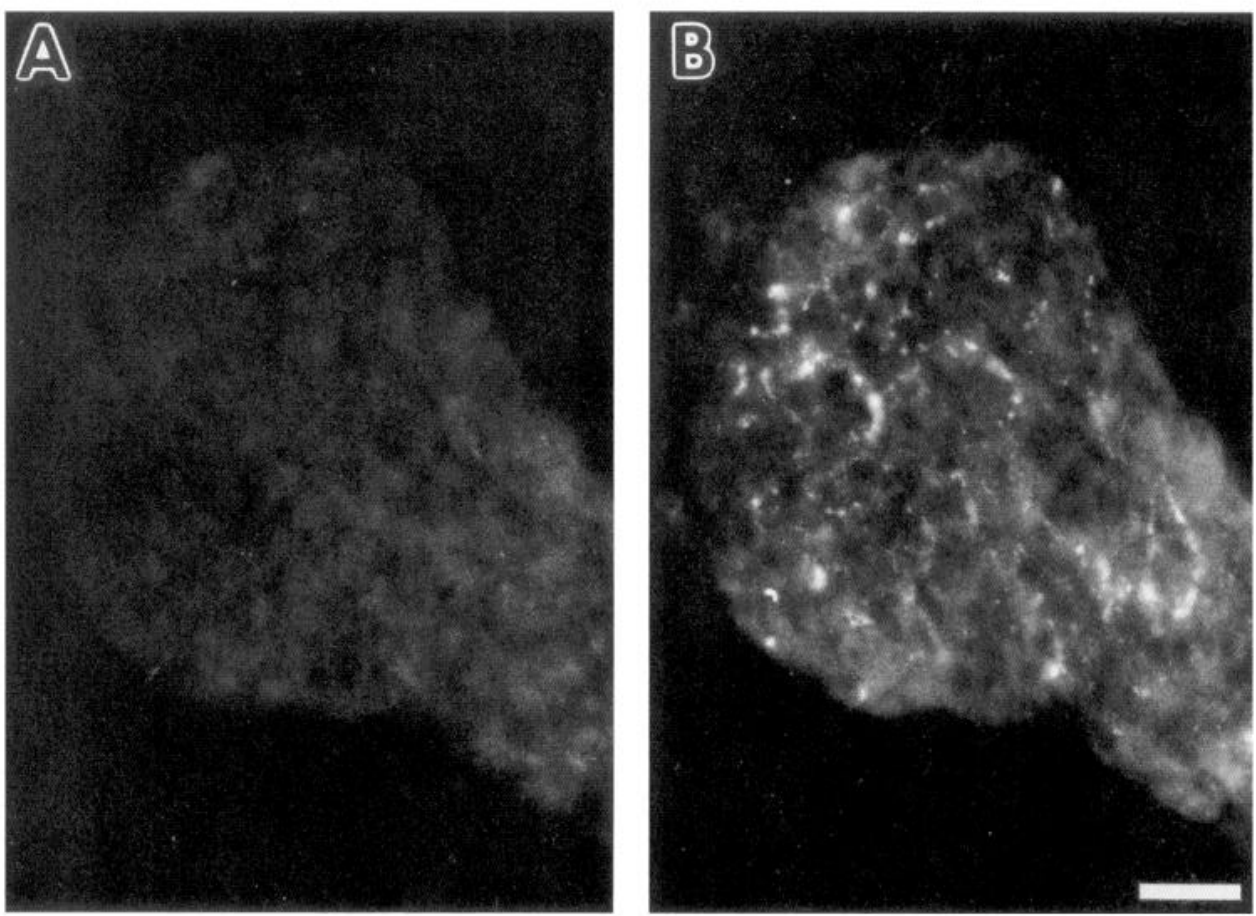

\section{Ganglionic transmission}

To study the effect of morphine and DADLE on ganglionic transmission at both ciliary and choroid ganglionic synapses, the ciliary ganglion was removed (St 37-42) intact with an adequate length of preganglionic oculomotor nerve and postganglionic ciliary and choroid nerves to allow suction electrode extracellular stimulation and recording. Extracellular action potentials were recorded independently in both ciliary and choroid nerves following single-shock preganglionic nerve stimulation $(0.05$ $\mathrm{Hz}$ ) before and during drug application (see Meriney et al., 1987).

\section{Results}

\section{Quantitation of the developmental distribution of endogenous LE-like immunoreactivity in the ciliary ganglion}

To quantitate the localization and developmental distribution of opioid peptide staining, LE-like immunoreactivity was compared to that of an antibody that recognizes an antigen associated with synaptic vesicles (SV2; Buckley and Kelly, 1985). Presynaptic terminals characteristic of both ciliary and choroid neurons stained for LE-like peptides at St 40 (near the end of the cell death period; see Fig. 1). Developmentally, the distribution of LE staining before the normal neuronal death period (St 30) showed a fine network of fibers that were not organized into recognizable terminals, and no specific SV2 staining was apparent (Fig. 2). By St 35, LE-like immunoreactivity appeared as a combination of punctate-staining fibers running around characteristic ciliary and choroid nerve terminals (Fig. 3). Although electrophysiologically the number of functional synapses is increasing during this early time (Landmesser and Pilar, 1974a,b), many of these contacts are onto somal processes (which are later retracted) extending from the ganglion cells. This may explain the relatively small number of terminals with characteristic morphology that can be observed at this age. By St 37, the number of LE-positive terminals has increased (Fig. 4). At this time, about $50 \%$ of the terminals expected in the section were clearly labeled with the SV2 antibody. At St 40 , all of the cell bodies counted had closely apposed presynaptic terminals that contained sufficient SV2 antigen to be labeled, and about $30 \%$ of these also stained for LE (Figs. 4, 5). Subsequently, the number of LE-stained terminals decreased between the end of the cell death period and hatching (St 40-45), such that only $2 \%$ of the SV2-containing terminals also stained for LE. This low level of LE staining was maintained in the adult chicken. Although separate counts of ciliary and choroid terminals were not made, there did not appear to be a large change in the distribution of LE during development.

These observations are summarized in Figure 4. Since there are two developmental phenomena occurring at the same time (the formation of synapses and the expression of opioid peptides), the number of SV2-stained terminals was initially compared at various developmental stages with the number of cells in each section to estimate the total number of terminal profiles that could be resolved in each section. The open circles in Figure 4 serve as a control for the number of synaptic profiles that can be seen in each histological section. Note that by St 40 , all neurons have a clearly recognizable presynaptic terminal. Rather than use these counts to create a correction factor, we plotted these values on the same graph with the quantitation of LE-like immunoreactivity. In this case, we have represented these data as a ratio of LE-like staining to SV2 staining to determine the percentage of recognizable terminals at each developmental stage that showed LE-like immunoreactivity (see Fig. 4). Therefore, the data in Figure 4 allow a comparison between the number of neurons that have a recognizable synaptic profile (open circles) and the number of those profiles that also stain for LE-like peptides (solid circles). We chose this presentation to emphasize that, early in the cell death period, the proportion of cells with LE-reactive endings is much larger than is observed later. In other words, LE-like immunoreactivity is decreasing over the 


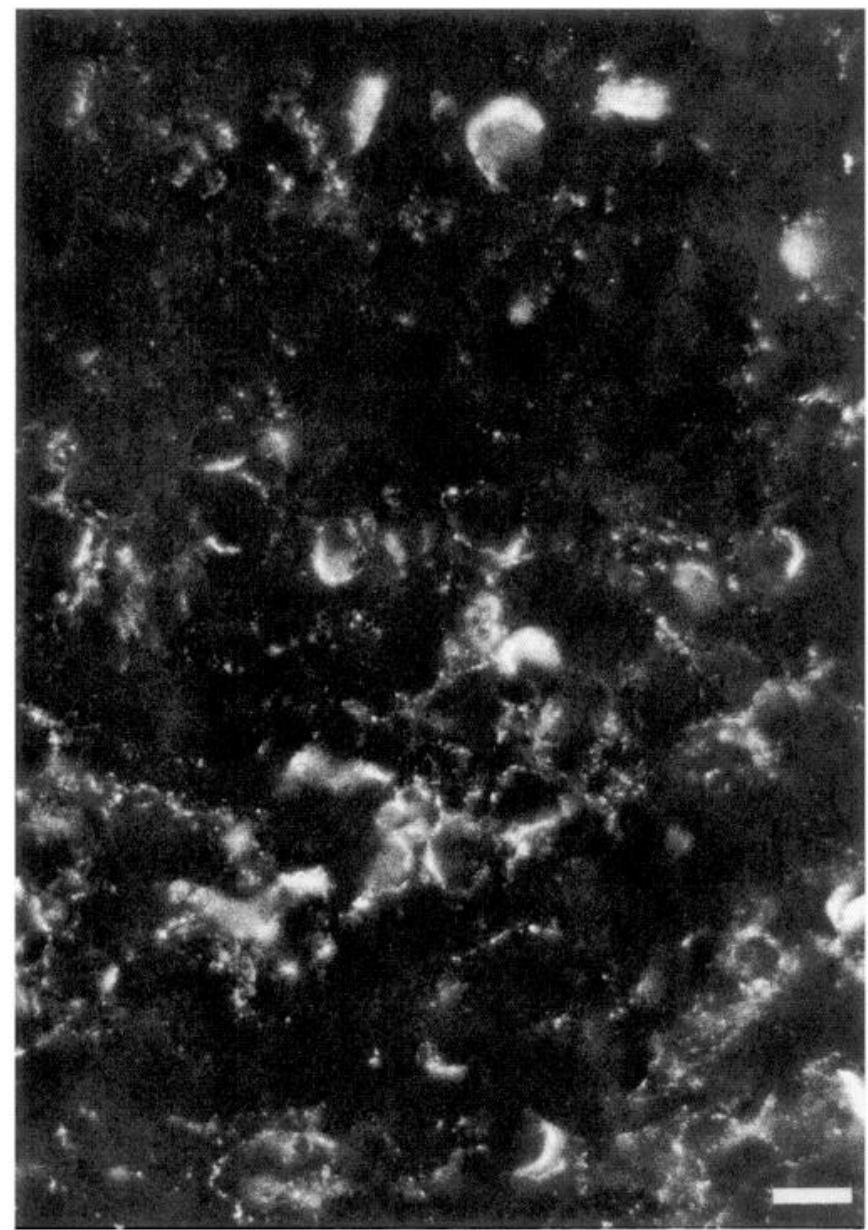

Figure 3. LE-like immunoreactivity in the St 35 ciliary ganglion appeared as a widespread punctate network of fibers surrounding distinct terminal endings onto ciliary and choroid cells. Scale bar, $20 \mu \mathrm{m}$.

same time period during which the number of neurons with recognizable endings is increasing. Therefore, there appears to be a specific developmental window that coincides with synapse formation in the ganglion and the normal neuronal competition for survival, during which endogenous opioid peptides are present within presynaptic terminals onto ciliary ganglion neurons. Interestingly, the relative absence of LE-like immunoreactivity in the chick ciliary ganglion after hatching is in sharp contrast to the presence of a high percentage of LE-like staining within presynaptic terminals onto adult pigeon ciliary ganglion neurons (see Erichsen et al., 1982).

\section{LE-like immunoreactivity within preganglionic neurons in the midbrain}

The avian analog of the Edinger-Westfal nucleus is located in the midbrain and contains the cell bodies that elaborate the presynaptic nerve terminals onto both ciliary and choroid neurons of the ciliary ganglion. Initially, we attempted to combine selective retrograde labeling [using $1,1^{\prime}$-dioctadecyl-3,3,3',3'tetramethyl-indocarbocyanine perchlorate (DiI); Molecular Probes, Eugene, OR] of these preganglionic midbrain neurons with immunostaining for $\mathrm{LE}$ at different developmental stages. Despite extensive efforts, we were unable to keep the excised midbrain-ciliary ganglion system viable for a long-enough pe-

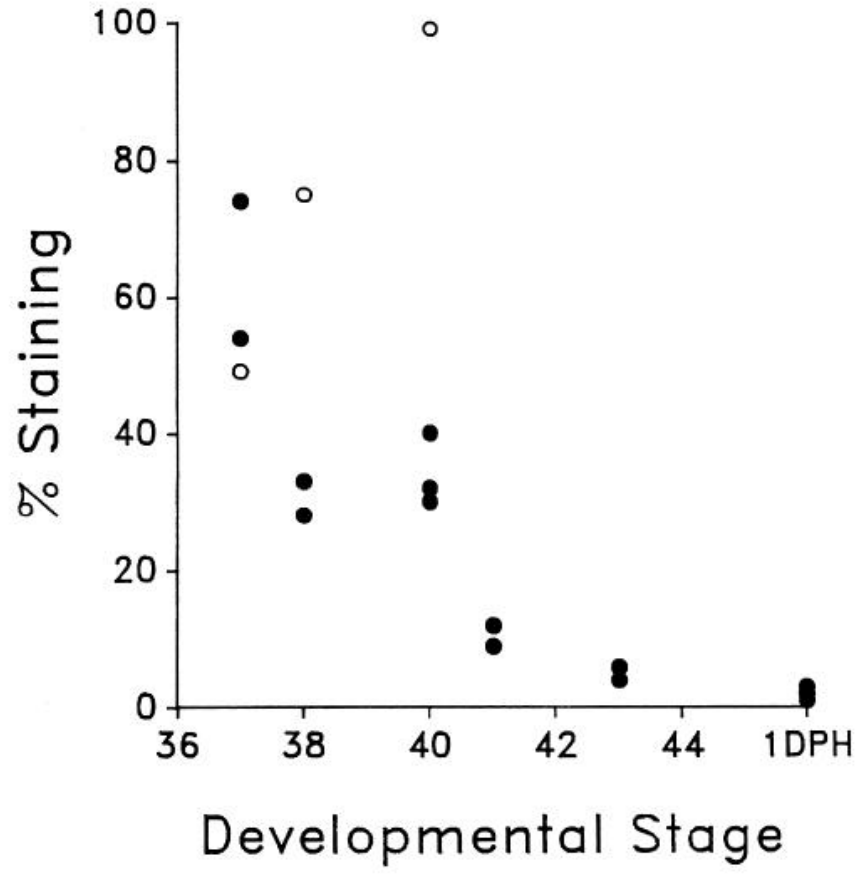

Figure 4. Graphic representation of the quantitation of the developmental changes in SV2 and LE-like immunoreactivity in ciliary ganglia The number of SV2-positive profiles that could be resolved (expressed as a percentage of the number of cells; open circles) increased sharply between St 37 and St 40. By St 40, almost all of the cells seen in each section were associated with an SV2-labeled synaptic profile. However, during this same time period, the number of SV2-labeled profiles that also stain for LE decreased sharply (number of LE-stained profiles is expressed as a percentage of the number of SV2-labeled profiles; solid circles).

riod to allow complete retrograde transport of Dil and also allow immunoreactivity for LE to be preserved. Therefore, here we report the qualitative developmental appearance of LE-like immunoreactivity. At embryonic stages that coincide with the cell death period in the ciliary ganglion (St 35-40), the LE-like immunoreactivity in the cell bodies of the Edinger-Westfal nucleus was highest (Fig. 6). After hatching, however, LE-like immunoreactivity could not be detected (despite many attempts to enhance detection with a 24-hr exposure to colchicine prior to dissection). This is in sharp contrast to immunoreactivity that we detected in side-by-side experiments in the pigeon after hatching (see also Erichsen et al., 1982). These observations are qualitatively consistent with the time course of staining seen in nerve terminals onto chicken ciliary ganglion cells (described above).

\section{Ciliary ganglion numbers}

As we reported earlier (Meriney et al., 1985), daily administration of an increasing dose of morphine (20-200 $\mu \mathrm{g} / \mathrm{d}$; assumed to be about $1-10 \mu \mathrm{M}$ in the embryo) during the normal neuronal death period prevents most of the neuronal degeneration. The normal neuronal degeneration occurs between E8 (St 34), when 6260 cells are present, and E14 (St 40), when 3704 remain. Daily morphine administration delayed this effect to the extent that 5948 cells were alive at E14 (Meriney et al., 1985). This effect was also shown to be reversed by the opiate receptor blocker naloxone. However, daily administration of naloxone alone during the cell death period did not significantly change 

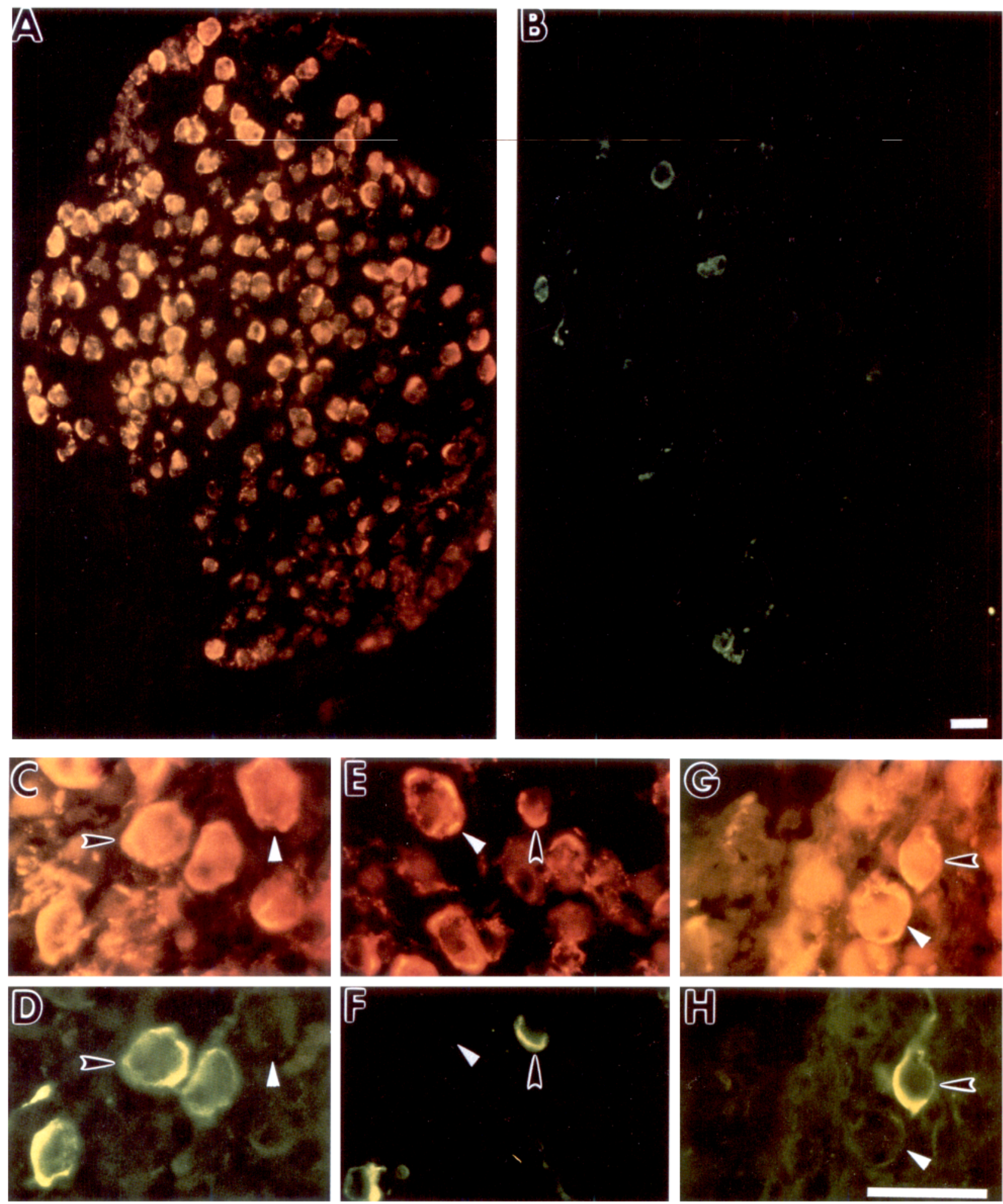

Figure 5. Double labeling of St 40 ciliary ganglia with antibody to LE (fluorescein labeled) and the SV2 monoclonal antibody (rhodamine labeled) revealed that only a portion of the terminals that stain positive for SV2 also stain for LE. $A$, Low magnification of SV2 immunoreactivity. $B$, Low magnification LE-like staining in the same section. $C, E$, and $G$, Higher-magnification examples of SV2-labeled nerve terminals paired with LElike staining $(D, F$, and $H)$ in the same section. Although some terminals stained for both antigens (black arrowheads), many only stained for SV2 (white arrowheads). Scale bars, $20 \mu \mathrm{m}$.

the neuronal number after the cell death period (4098 cells alive at E14; Meriney et al., 1985).

Since exogenous morphine prevents much of the neuronal death, if an endogenous opioid peptide is modulating the normal cell death, opiate receptor blockade would be expected to result in a more pronounced neuronal death. For this experiment, we chose to use the opiate antagonist naltrexone because it has a longer half-life than naloxone ( $3 \mathrm{hr}$ vs. $1 \mathrm{hr}$; Gilman et al., 1990). 

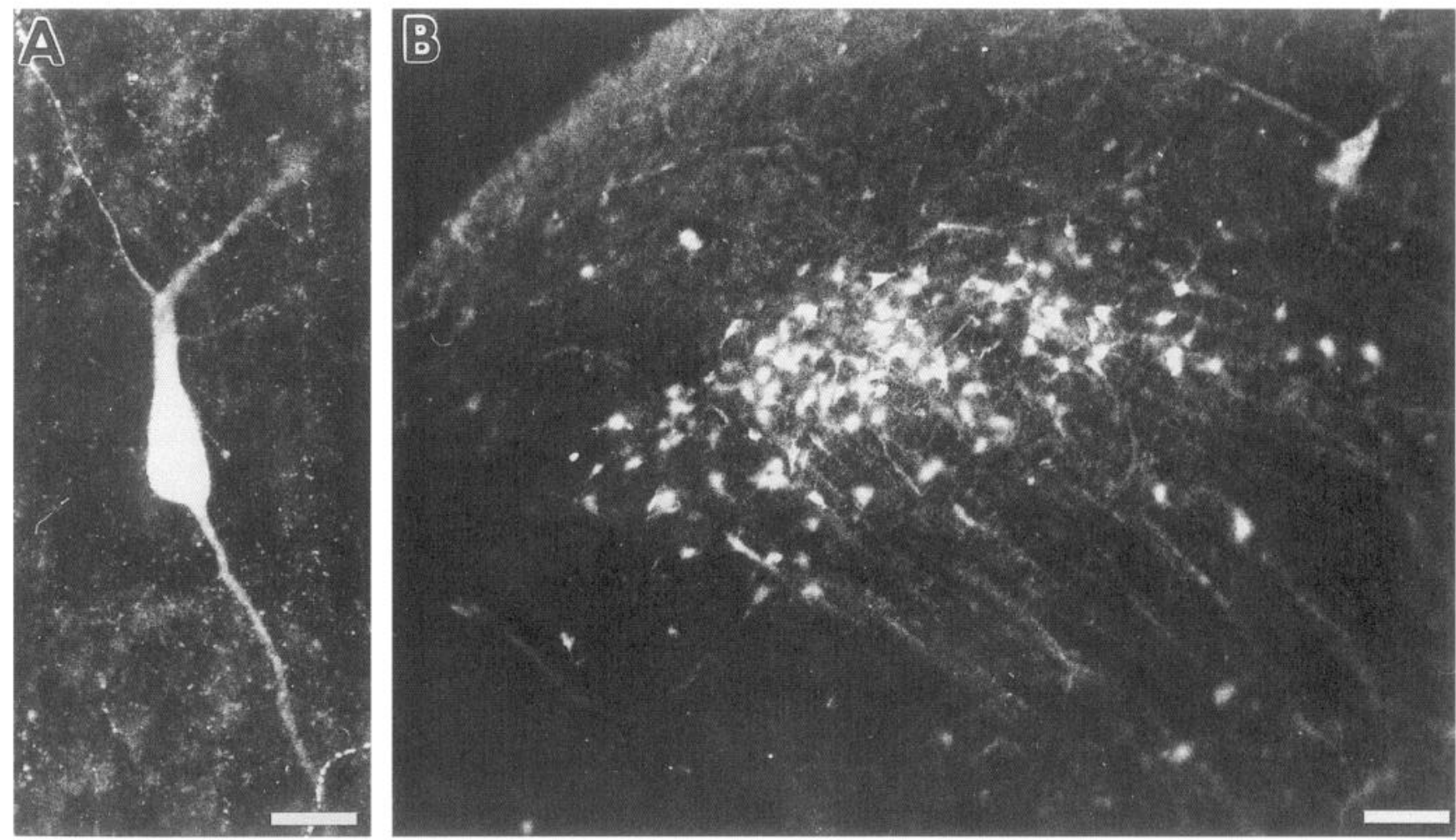

Figure 6. St 40 LE-like immunoreactivity in the avian analog of the Edinger-Westfal nucleus of the midbrain. $A$, An enlarged view of an EdingerWestfal neuron stained with LE antibody. The intense staining of many individual neurons reveals a long axonal process, and two or three dendritic processes that often extend for more than $40 \mu \mathrm{m}$. $B$, A low-magnification view of the nucleus. Scale bars, $A, 10 \mu \mathrm{m} ; B, 50 \mu \mathrm{m}$.

Since a total and maintained block of endogenous opioids is essential for this experiment, we administered naltrexone once every $8 \mathrm{hr}$ (three times daily). Extrapolating from data obtained in humans, this application protocol is not likely to result in an accumulation of the drug and should block opiate receptors for most of the time between applications. When naltrexone was administered three times daily during the neuronal death period (once every $8 \mathrm{hr}$ ), a significantly smaller number of neurons compared to controls survived the normal cell death period (Table 1). Since naltrexone is a pure opiate antagonist, in the absence of cytotoxic effects, this is what would be expected if endogenous opioids normally influence neuronal survival. Interestingly, when naltrexone was given only once daily throughout the normal death period, an increase in neuronal survival was readily apparent (see Table 1). In summary, while administration three times daily decreased survival, single daily administration increased survival.

An important part of our efforts was to determine if the effect of three times daily naltrexone administration was due to a direct toxicity to the ciliary ganglion neurons. As controls for the toxicity of three times daily naltrexone, we counted the number of spinal lumbar motoneurons following this treatment in the same embryos from which ciliary neuron counts were obtained. We selected this control population of cells because they are also cholinergic and undergo a similar competition for survival during development. The number of spinal motoneurons in naltrexone-treated animals was not significantly different with either application protocol described above (E5-14 or E714); therefore, the numbers are pooled in Table 1. Since the number of spinal lumbar motoneurons was not significantly affected by three times daily naltrexone treatment $(14,355$ vs. 14,328 ), we do not believe the treatment paradigm described above was toxic to the ciliary ganglion neurons in vivo. The selective effect of naltrexone on the neurons of the ciliary ganglion also argues against any systemic hormonal modulation that may have generally affected neuronal survival (see Howlett and Rees, 1986). As an additional control, naltrexone-treated ciliary ganglia were examined in the electron microscope and compared with those from control ganglia (see Pilar and Landmesser, 1976). Surviving neurons treated three times per day

\begin{tabular}{|c|c|c|}
\hline \multirow[b]{2}{*}{ Treatment } & \multicolumn{2}{|c|}{ Neuronal number } \\
\hline & E8 & E14 \\
\hline \multicolumn{3}{|l|}{ Ciliary ganglion } \\
\hline $\begin{array}{l}\text { Control } \\
\text { Naltrexone }\end{array}$ & $6260 \pm 339(9)$ & $3560 \pm 132(11)$ \\
\hline $\begin{array}{l}(20 \mu \mathrm{g} / \mathrm{d}) \\
3 \times \text { Naltrexone }\end{array}$ & & $5439 \pm 297(10)^{* *}$ \\
\hline$(20 \mu \mathrm{g} / 8 \mathrm{hr})$ & & $2818 \pm 35(10)^{*}$ \\
\hline \multicolumn{3}{|c|}{ Lumbar spinal motoneurons } \\
\hline Control & & $14,355 \pm 78(2)$ \\
\hline $\begin{array}{l}3 \times \text { Naltrexone } \\
(20 \mu \mathrm{g} / 8 \mathrm{hr})\end{array}$ & & $14,328 \pm 944(6)$ \\
\hline
\end{tabular}

Numbers in parentheses indicate the number counted for each treatment. ${ }^{* *}, p<$ $0.001 ;{ }^{*}, p<0.03$ (significantly different from control as judged by one-way ANOVA using Tukey's test). 

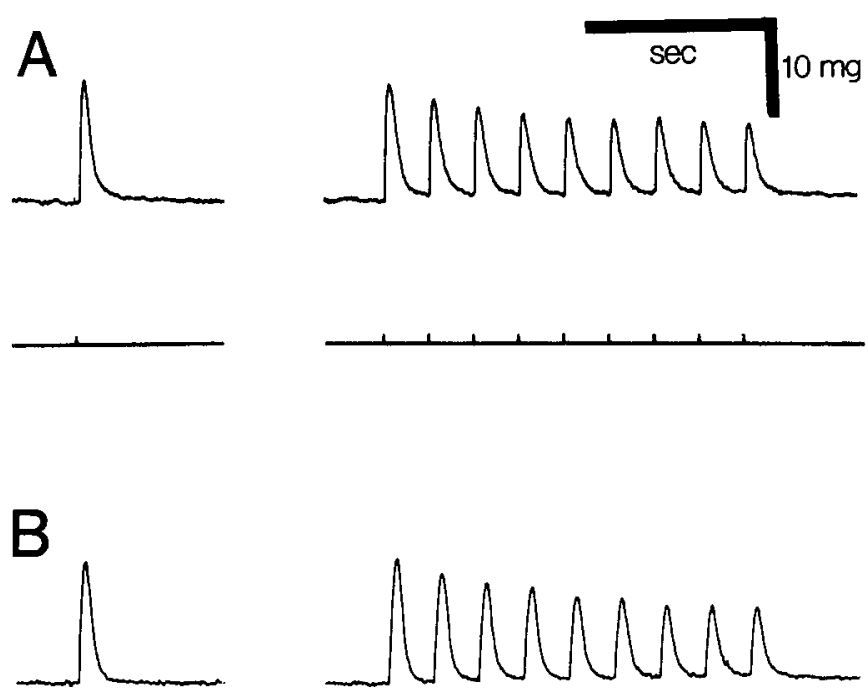

Figure 7. Strain gauge measurements of iris force in response to ciliary nerve stimulation. $A$, Control iris. $B$, A $30 \mathrm{~min}$ incubation in $75 \mu \mathrm{M}$ morphine did not block contractions either following a single shock or during a $5 \mathrm{~Hz}$ nerve stimulation.

with naltrexone were ultrastructurally indistinguishable from controls at E14 (eccentric nucleus, well-organized rough endoplasmic reticulum distributed in the periphery of the cytoplasm, and well-developed pre- and postsynaptic specializations; data not shown).

To further control for the possibility that three times daily application of naltrexone was toxic to ciliary neurons, we exposed cultured ciliary ganglion neurons to various concentrations $(0.02-200 \mu \mathrm{g} / \mathrm{ml})$ of naltrexone. In this assay, naltrexone was shown not to be toxic at concentrations as high as $200 \mu \mathrm{g} /$ $\mathrm{ml}$. For comparison with the in vivo application protocol, we estimate that each application of naltrexone $(20 \mu \mathrm{g})$ is dissolved into an egg volume of $25 \mathrm{ml}$. In the absence of information concerning drug partitioning, metabolism, and so on, it is a rough estimation to suspect that each application would expose the embryo to $0.8 \mu \mathrm{g} / \mathrm{ml}$ naltrexone. Since we have shown that naltrexone is not toxic to ciliary neurons in vitro at concentrations up to $200 \mu \mathrm{g} / \mathrm{ml}$, it is not likely that the three times daily application of naltrexone to the egg is directly toxic to the ciliary ganglion neurons.

\section{Opiate effects at ganglionic and neuromuscular synapses}

To address the question of the mechanism by which opiates influence ciliary ganglion neuron survival, the effects of morphine on synaptic transmission during the normal neuronal death period were examined. It is well documented that neuromuscular paralysis by acetycholine $(\mathrm{ACh})$ receptor blockers prevents motoneuron death (Pittman and Oppenheim, 1978, 1979; Meriney et al., 1987). Morphine has been shown to decrease by $40 \%$ spontaneous hindlimb kicks in the developing chick embryo (Maderdrut et al., 1985). However, this decrease in hindlimb kicking, the site of action of which is not known, is not sufficient to influence spinal motoneuron death (see Meriney et al., 1985). Complete neuromuscular paralysis is thought to be required to prevent normal motoneuron death (see Pittman and Oppenheim, 1979). If morphine-induced modulation of ciliary ganglion neuron survival occurs via blockade of neuromuscular transmission, complete paralysis of the striated iris muscle would be expected (see Meriney et al., 1987). Morphine's effect on nerve-evoked iris muscle contractions was investigated with both pupillomorphic observations of acute and chronically treated embryos and force transducer measurements of acutely treated irises. Morphine, up to $75 \mu \mathrm{M}$, did not inhibit the constriction of the pupil following either single-shock or $5 \mathrm{~Hz}$ ciliary nerve stimulation in acutely treated preparations (Fig. 7). In addition, some of the chronically treated embryos used for neuronal cell counts were also used for pupillomorphic observations. Figure 8 shows a chronically treated iris before and during a $30 \mathrm{~Hz}$ ciliary nerve stimulation. It is apparent that morphine does not paralyze iris neuromuscular transmission even in chronically treated embryos. It is still possible that opiates exert a morc subtle effect on this synapse that is not detected with tension measurements or pupillomorphic observations. However, since complete paralysis has been shown to be necessary for an activity-dependent delay of motoneuron death, a subtle effect of morphine on synaptic transmission is unlikely to influence neuronal survival significantly.

The effect of morphine on nerve-evoked contractions in the target smooth musculature of the choroid neurons was also examined. Figure $9 A$ shows the tension generated in the choroid muscle in response to a $30 \mathrm{~Hz}$ choroid nerve stimulation. When $50 \mu \mathrm{M}$ morphine was added to the perfusion solution, the contractile response decreased significantly (Fig. $9 B$ ). Therefore, morphine can partially block the nerve-evoked activation of the choroid coat. This is consistent with biochemical measurements from embryonic choroid tissue of a significant opiate inhibition of ACh release (Gray et al., 1989).

Activity at ganglionic synapses within the ciliary ganglion is also known to regulate the extent of the normal neuronal death. ACh receptor blockade of these synapses during development increases the extent of degeneration among both ciliary and choroid neurons (Wright, 1981). Since it is known that endogenous opiates exist in large quantities within the ciliary ganglion during this period in development, the effect of morphine on transmission across these synapses was investigated. At St 37 , administration of up to $20 \mu \mathrm{M}$ morphine for $30 \mathrm{~min}$ did not block ciliary or choroid ganglionic transmission (Fig. 10A,B). At St 39 (Fig. 10C,D), morphine partially blocked choroid transmission but did not appear to influence ciliary transmission. However, by St 41 (Fig. 10E,F), $10 \mu \mathrm{M}$ morphine partially blocked both ciliary and choroid ganglionic transmission. Therefore, during the early portion of the cell death period (St 37), morphine did not block ganglionic transmission. At the end of this devclopmental window (St 39-41), morphine partially blocked synaptic transmission across the ganglion.

\section{Effects of DADLE on ganglionic transmission}

Since endogenous LE-like opioids may be available in relatively large quantities, especially during the early portion of the normal cell death period, and since morphine appears to be most potent in blocking ganglionic transmission at later developmental stages, we examined the sensitivity of ganglionic transmission to DADLE (an LE analog). At St 37 (when LE immunoreactivity is high; see Fig. 4), a $10 \mathrm{~min}, 10 \mu \mathrm{M}$ DADLE administration partially blocked transmission across both ciliary and choroid synapses (Fig. 11A,B). By St 42, the effect was most evident at 

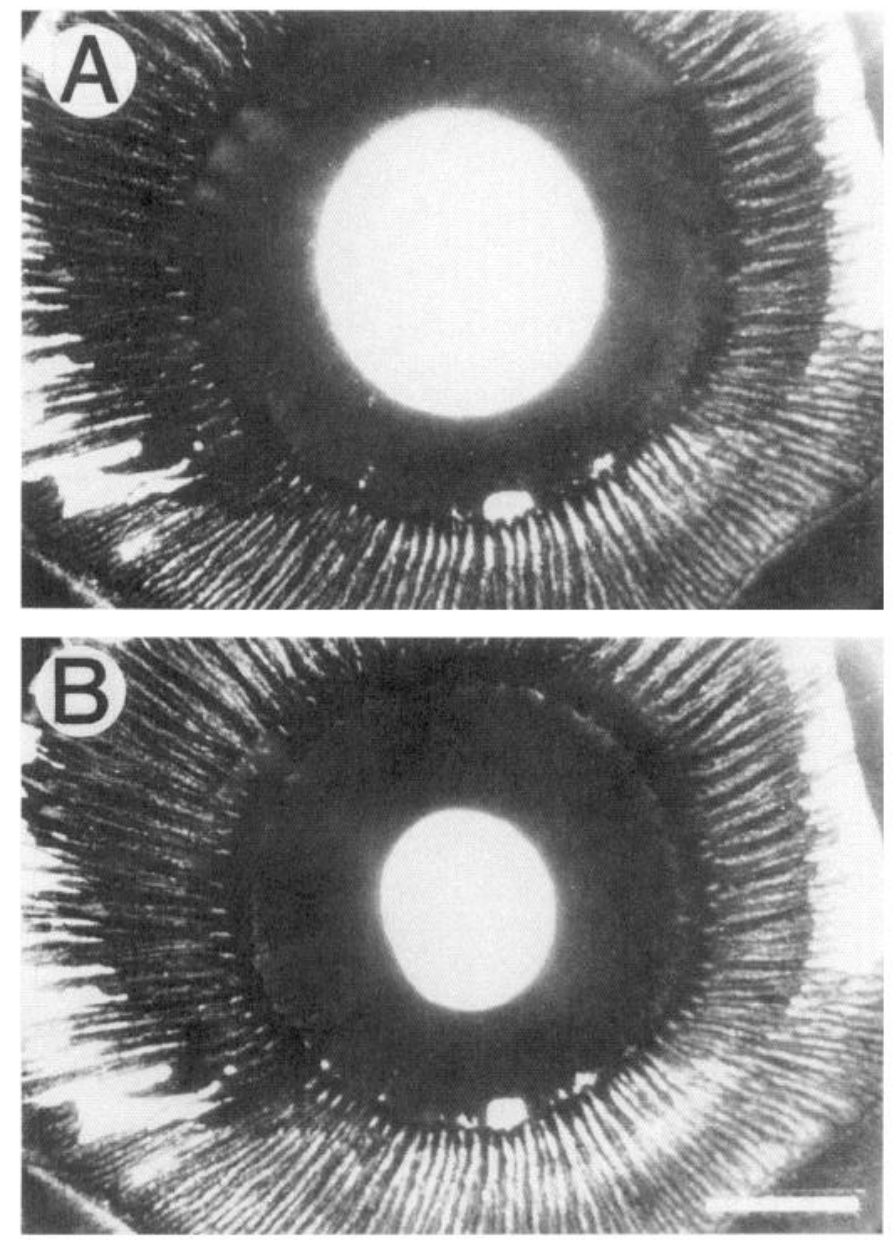

Figure 8. The effect of chronic morphine treatment on St 41 iris pupil constrictions. $A$, Chronically treated resting pupil. $B$, Iris constriction of the chronically treated muscle during a $30 \mathrm{~Hz}$ ciliary nerve stimulation. Morphine administration was never able to paralyze iris constriction. Scale bar, $30 \mu \mathrm{m}$.

choroid synapses and was completely blocked by prior exposure to $10 \mu \mathrm{M}$ naloxone (Fig. $11 C-F$ ).

Although we cannot distinguish between pre- and postsynaptic effects, it is clear that DADLE has a greater effect on ganglionic transmission at St 37, when endogenous LE immunoreactivity is highest, than after the cell death period. In addition, this is in sharp contrast to the effects of morphine on ganglionic transmission, since morphine does not have any effect at St 37 and gradually begins to block by St 39 .

\section{Discussion}

Exogenous morphine administration throughout the normal cell death period increases the number of neurons that survive (Meriney et al., 1985). Since endogenous opioid peptides are expressed in large amounts in the chick ciliary ganglion predominantly during the cell death period, we have investigated the hypothesis that they modulate the normal neuronal death (White et al., 1985; see below). There are three major lines of evidence that support this hypothesis: (1) exogenous opiate agonist application increases neuronal survival, and this effect can be reversed by naloxone (Meriney et al., 1985); (2) application of an opiate antagonist can decrease neuronal survival; and (3) LE-
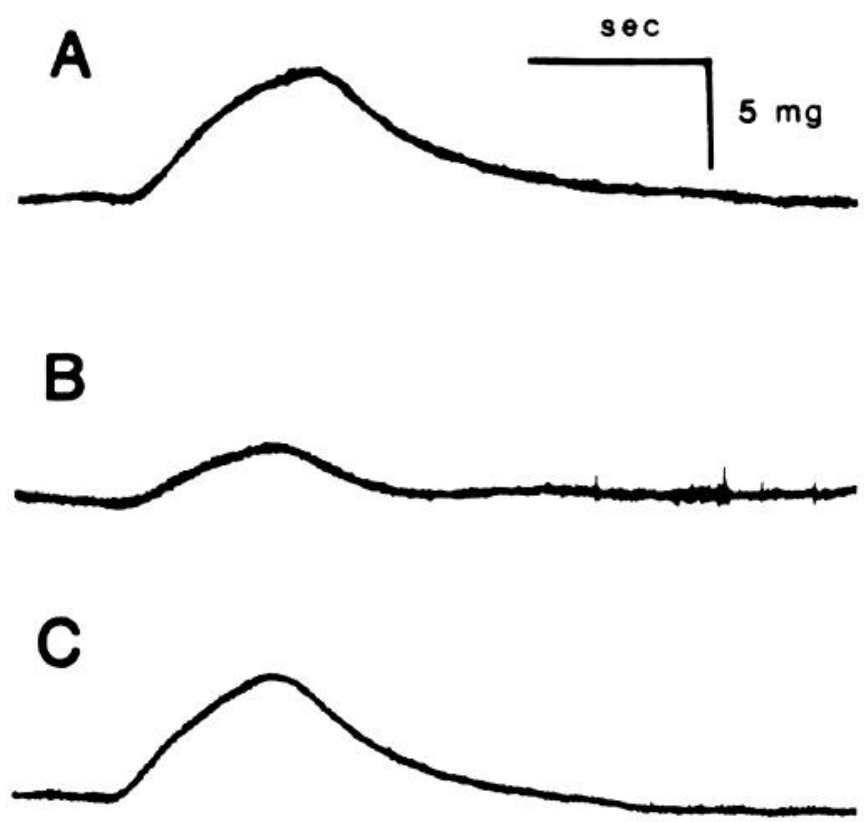

Figure 9. The effects of acute morphine $(50 \mu \mathrm{M})$ on the contraction elicited by $30 \mathrm{~Hz}$ nerve stimulation in the St 44 choroid coat. $A$, Control. $B$, Morphine significantly decreased the contraction elicited by choroid nerve stimulation. $C$, Following a $20 \mathrm{~min}$ washout period, the effect of morphine was reversed.

like immunoreactivity is transiently expressed during the neuronal death period within presynaptic nerve endings onto ciliary ganglion neurons.

One important experimental evidence presented in this article is the effect of naltrexone on neuronal survival. When naltrexone was administered to the chick embryo three times during a 24 $\mathrm{hr}$ period, a decrease in ciliary ganglion neuron survival was observed. It is likely that this multiple application protocol blocks the opiate receptors for most, if not all, of the $24 \mathrm{hr}$ period. Therefore, the ciliary ganglion neurons may be deprived of an endogenous opioid influence, and fewer neurons survive the normal cell death period. This effect is not likely to be due to a toxic effect of the three times daily naltrexone treatment, since lumbar spinal motoneurons from the same embryo were unaffected, and an in vitro assay of naltrexone toxicity showed no toxic effects. Therefore, since naltrexone appears to modify ciliary ganglion neuronal survival specifically and selectively, these results strongly suggest that endogenous opioid peptides modulate the neuronal degeneration that occurs during development, increasing the probability that neurons will survive the competition for survival.

Interestingly, when the opiate receptor antagonist naltrexone was administered only once daily to the embryo, there was an increase in neuronal survival (an effect expected from an opioid agonist in the ciliary ganglion). We were initially surprised by this effect. Previously, it has been established that naltrexone, a long-acting opiate antagonist interacting with many types of opiate receptors, only has an effect after opiate administration or activation of an endogenous opioid system, and has no known agonist activity (Martin, 1983). Alternatively, Zagon and 

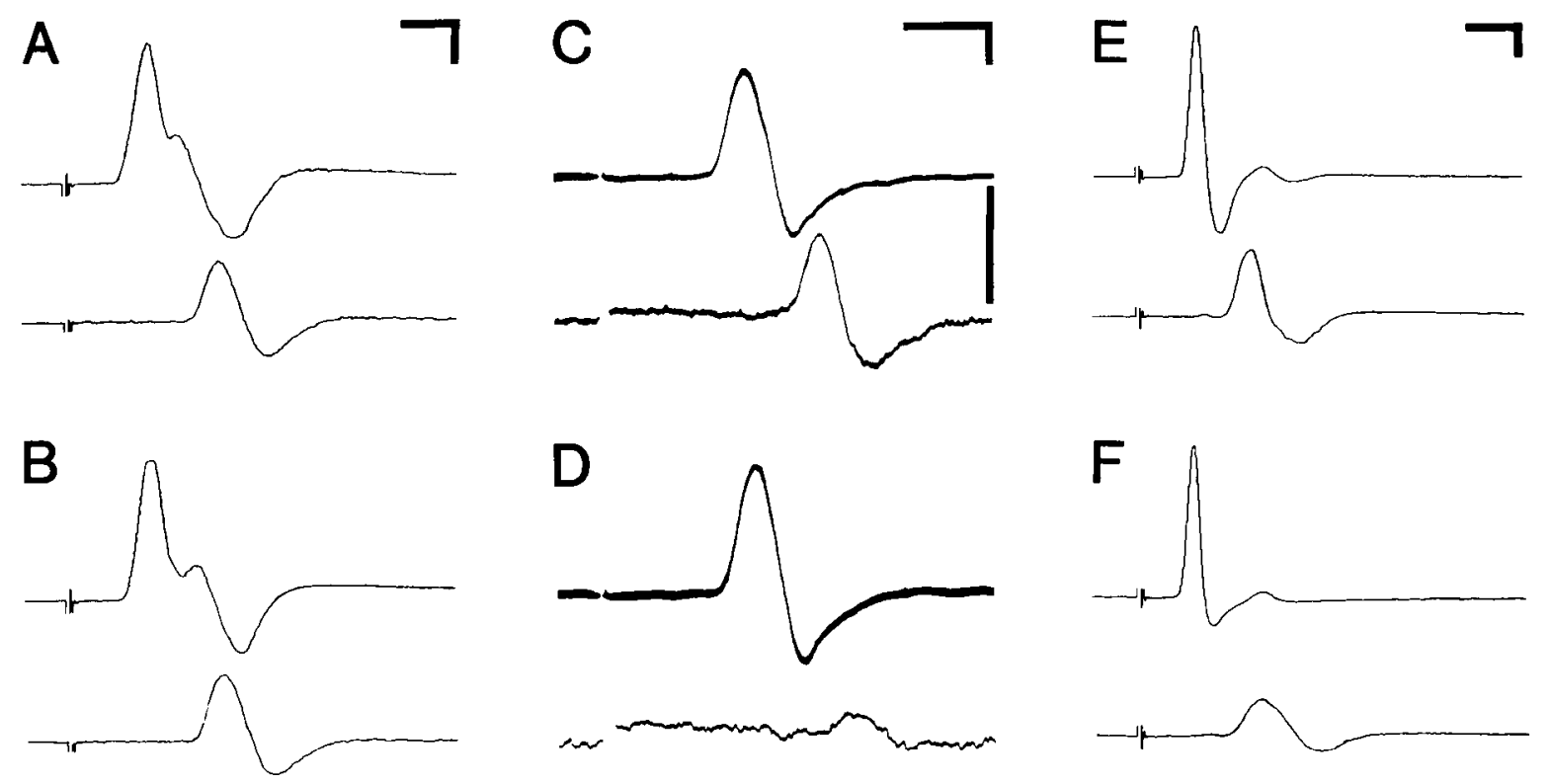

Figure 10. The effects of acute morphine administration on ciliary (top traces) and choroid (bottom traces) ganglionic transmission during development. $A$, St 37 control. $B$, A 30 min exposure to $20 \mu \mathrm{M}$ morphine did not significantly affect either ciliary or choroid ganglionic transmission at St 37. C, St 39 control. $D$, A 10 min exposure to $10 \mu \mathrm{M}$ morphine significantly blocked only choroid ganglionic transmission. $E$, St 41 control. $F$, A 10 min exposure to $10 \mu \mathrm{M}$ morphine partially blocked both ciliary and choroid ganglionic transmission. Calibration: $200 \mu \mathrm{V}, 10 \mathrm{msec}$.

McLaughlin $(1984,1986)$ have shown that chronic administration of opiate antagonists can produce an agonist effect if receptor blockade persists for only $4-6 \mathrm{hr}$ following the injection. This is hypothesized to occur as a result of an upregulation of opiate receptors during the receptor blockade, which subsequently enhances endogenous opioid activation between antagonist injections; a similar explanation could be used to explain our data following single daily injections of naltrexone (see Schultz et al., 1979; Zukin et al., 1982; Bardo et al., 1983; Zagon and McLaughlin, 1986).

We have extended the observations of White et al. (1985) to document the dynamic changes in opioid expression that occur within presynaptic terminals onto chick ciliary ganglion cells and shown that endogenous opioids are transiently expressed in the ganglion only during the cell death period, and only in some terminals. It is not likely that the loss of LE-like immunoreactivity following the cell death period is due to the selective death of enkephalin-containing Edinger-Westfal neurons since we have observed a downregulation of LE-like immunoreactivity in Edinger-Westfal neurons following the normal neuronal death period in the ciliary ganglion. The expression of opioids in the nerve terminals onto ciliary ganglion neurons appears to be a developmentally regulated phenomenon. In fact, we found that no more than about $50 \%$ of terminals were labeled at any one time. We could not determine whether all terminals were immunoreactive, but we consider it likely that opioids are transiently expressed in all terminals at some time during the $5 \mathrm{~d}$ cell death period. It is possible that opioid expression is actively reduced, perhaps by some retrograde transynaptic signal, in individual terminals after their effect on neuronal survival has been achieved. Interestingly, a striking difference in the percentage of terminals labeled with LE antibodies is apparent when the hatched chicken is compared to the pigeon (Erichsen et al., 1982). In the chicken, only $2 \%$ of terminals stain for LE, while about $54 \%$ are strongly immunoreactive in the pigeon. This difference is also apparent among the parent cell bodies in the Edinger-Westfal nucleus (described earlier). It is clear that the developmental regulation of LE-like peptides is different in the pigeon and chicken. We do not know the reason for this difference, but it is interesting to note that the pigeon ciliary ganglion has about twice as many neurons as the chicken ciliary ganglion (Marwitt et al., 1971) and may not have the same magnitude of cell loss during development, which could indicate a different balance of interaction between target influences and opioid influences.

Recently, a transient expression of various neurotransmitters in the developing neocortex has led to the speculation that there is a series of chemical messengers expressed at different developmental times that influence the establishment of specific circuitry in the cortex (Parnavelas and Cavanagh, 1988). In some instances, it appears as if these neurotransmitters are exerting a trophic influence (see D'Amato et al., 1987). Many neuropeptides have also been shown to have growth promoting activity (see Zachary et al., 1987). In particular, endogenous opioids have also been shown to exert a trophic influence in postnatal rat brain, with a small increase in neuronal, and a large increase in glial proliferation observed in the cerebellum following daily naltrexone treatment during the first 3 weeks of life (Zagon and McLaughlin, 1986, 1987; Schmahl et al., 1989). In addition, continuous naltrexone treatment has been shown to increase dendritic growth and spine formation in the hippocampus, cerebral cortex, and cerebellum (Hauser et al., 1987, 1989). Therefore, since endogenous opioids are present at ganglionic synapses in large quantities during the ciliary ganglion cell death period, and three times daily naltrexone treatment selectively decreases ciliary ganglion neuron survival, endogenous opioids also appear to exert a trophic influence on these neurons.

Although opiates are known to be modulators of synaptic activity, and normal neuronal death is sensitive to synaptic activity blockade, our results do not support the idea that opiates 


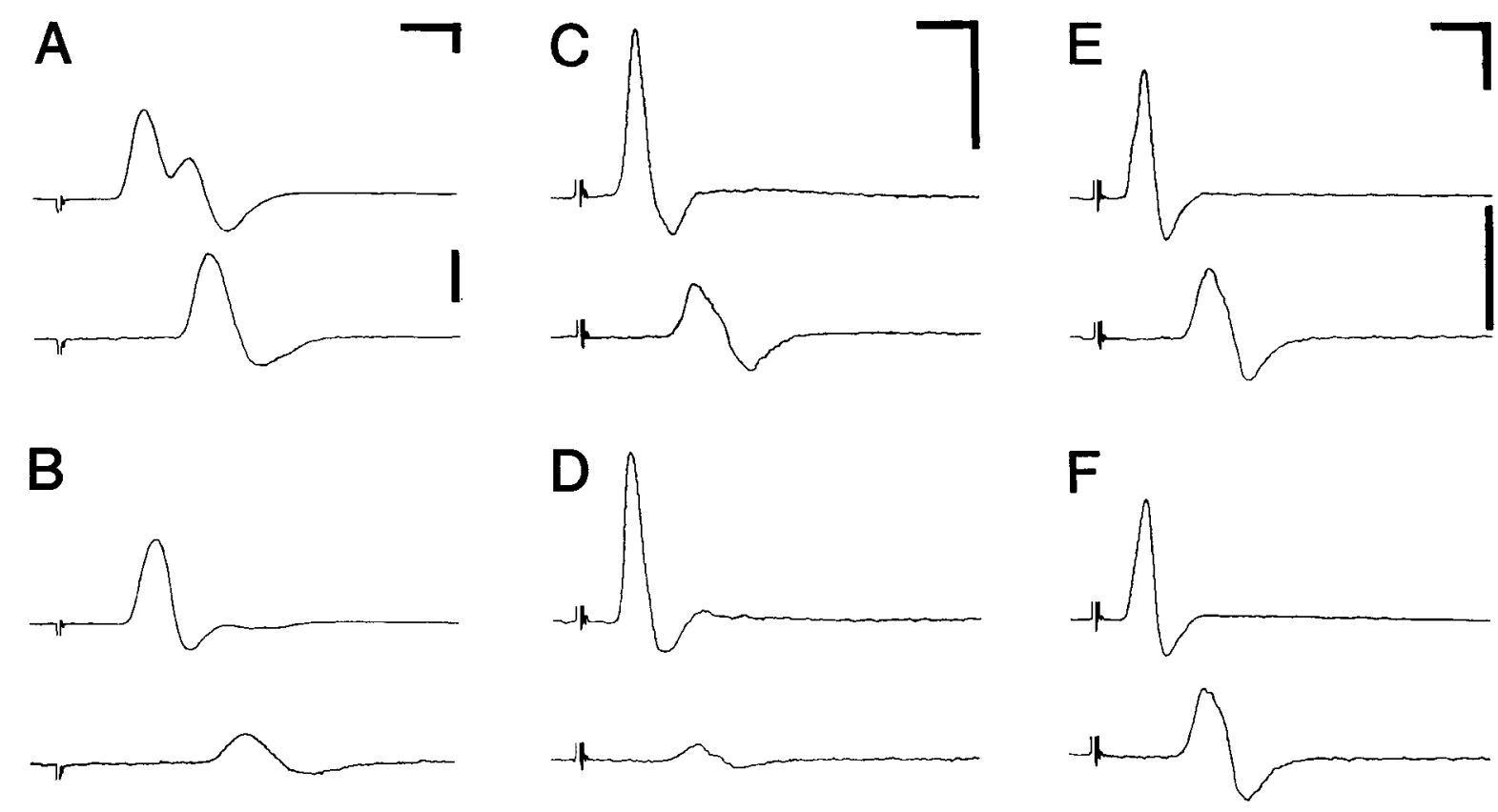

Figure 11. The effects of acute DADLE administration on ciliary (top traces) and choroid (bottom traces) ganglionic transmission during development in the ciliary ganglion. $A$, St 37 control. $B$, A 15 min exposure to $10 \mu \mathrm{M}$ DADLE partially blocked both ciliary and choroid ganglionic transmission. $C$, St 42 control. $D$, A 20 min exposure to $10 \mu \mathrm{M}$ DADLE only significantly affected choroid ganglionic transmission. $E$, St 42 control. $F$, Pretreatment with $10 \mu \mathrm{M}$ naloxone prevented the block of choroid ganglionic transmission following exposure to $10 \mu \mathrm{M}$ DADLE. Calibration: $200 \mu \mathrm{V}, 10 \mathrm{msec}$.

influence neuronal death via a paralysis-dependent mechanism for the following reasons. (1) Paralysis-induced regulation of ciliary ganglion survival occurs following a complete blockade of iris neuromuscular transmission. However, even chronic morphine treatment does not block nerve-evoked iris contractions. (2) In contrast, morphine significantly blocks activation of the smooth muscle of the choroid coat. This may not be relevant to choroid neuron survival since $\mathrm{ACh}$ receptor blockade at this synapse cannot rescue choroid neurons from normal neuronal death (Meriney et al., 1987). Therefore, this neuronal population does not appear to be regulated by peripheral synaptic blockade in the same way as the ciliary population. (3) Administration of exogenous morphine and DADLE can also block some choroid and ciliary ganglionic synapses. This is consistent with intracellular observations by Katayama and Nishi (1984), who describe synaptic inhibition by opiates in the rabbit ciliary ganglion. However, inhibition at these synapses by ACh receptor blockers is known to decrease neuronal survival (Wright, 1981), not increase survival, as we have observed with opioid agonists. Thus, it is apparent that the blockade of transmission at any of the synapses in the ciliary ganglion system observed following morphine administration is not likely to be the mechanism by which exogenous morphine increases neuronal survival, or the one by which endogenous opioids modulate the normal neuronal death.

Interestingly, morphine and DADLE do not appear to be equipotent in their ability to influence ganglionic transmission during the normal cell death period. Morphine does not have any effect at St 37, while DADLE is clearly able to influence synaptic transmission in the ganglion at this time. This suggests that $\delta$-opioid receptors predominate at ganglionic synapses during this early portion of the cell death period, which coincides with the highest expression of endogenous LE-like immuno- reactivity. Further investigation will be required to determine if a change in receptor pharmacology is occurring within the ganglion at this time. These observations, however, are only suggestive of the receptor pharmacology that influences ganglionic transmission. It is possible that effects of exogenously applied agonists and antagonists described above act at a different, perhaps nonsynaptic, site.

Morphine and the endogenous opioids may both act directly on the ciliary ganglion cells themselves. The endogenous opioids in the ciliary ganglion may modulate the normal neuronal death that occurs during development via a "paracrine" neurotrophic mechanism mediated by a second messenger. This may include intracellular messengers such as guanosine $3^{\prime}: 5^{\prime}$-cyclic monophosphate (cGMP), or simply calcium ions themselves. Weill and Greene (1984) reported that administration of the membrane-permeable dibutyryl cGMP to the chicken egg delays spinal motoneuron death, and we have reported a similar effect of dibutyryl cGMP on ciliary neurons (Meriney et al., 1984). In fact, morphine has been shown to increase cGMP levels in striatal slices (Minneman and Iversen, 1976). Alternatively, opioid modulation of voltage-sensitive calcium current may act to influence neuronal survival. Opiates have been shown to be potent blockers of $\mathrm{Ca}^{2+}$-dependent action potentials in ciliary ganglion neurons (Margiotta and Berg, 1986) and therefore are likely to modulate voltage-sensitive $\mathrm{Ca}^{2+}$ channels, decreasing $\mathrm{Ca}^{2+}$ influx. One hypothesis proposes that alterations in intracellular $\mathrm{Ca}^{2+}$ can affect neuronal death among trophic factordependent cells (see Koike et al., 1989). This " $\mathrm{Ca}^{2+}$ set-point hypothesis" predicts that there is an optimal level of intracellular $\mathrm{Ca}^{2+}$ concentration that allows for autonomous existence of the neuron. The idea was developed following observations that a chronic depolarization (induced by a mild high-potassium medium) increases the survival of sympathetic and ciliary ganglion 
neurons in vitro (Collins, 1988; Koike et al., 1989). Since $\mathrm{Ca}^{2+}$ channel blockers can prevent this effect, it is argued that an increase in intracellular $\mathrm{Ca}^{2+}$ ion concentration is critical for neuronal survival. The hypothesis predicts that developing neurons normally have a low intracellular free $\mathrm{Ca}^{2+}$ concentration and are therefore dependent on trophic factor support from the periphery. On the other hand, an excessively high intracellular $\mathrm{Ca}^{2+}$ concentration may be toxic to the neuron, as has been shown following excitatory amino acid exposure (Choi, 1988). It is possible that manipulation of the opioid effects on developing ciliary ganglion cells in vivo could alter the intracellular $\mathrm{Ca}^{2+}$ concentration, causing an imbalance in calcium homeostasis, and ultimately result in cell damage due to uncontrollable activation of calcium-dependent reactions (Choi, 1988; Slesjo, 1988).

Although the mechanism of exogenous morphine's delay of neuronal death is not known, it is not likely to replace the need for peripheral muscle interactions. When ciliary ganglion neurons are cultured in a medium of only minimum essential medium (MEM), vitamins, and amino acids, they quickly die (within $24 \mathrm{hr}$ ). Morphine is not able to shift the dose-response curve of the eye extract normally required for survival in vitro for 7 d (Gray, 1985). Perhaps, in vivo, morphine is able to act in concert with the variety of factors likely to be present. Morphine may "prime" ciliary neurons for support by trophic factors, or target-derived trophic support may change the sensitivity of ganglion cells to endogenous opioids or transsynaptically increase the expression of opioids in terminals onto ganglion cells. Furthermore, it is possible that exogenous opiates exert their effects in the target environment, where they may increase trophic support for ciliary ganglion neurons. However, this seems unlikely, since in preliminary unpublished experiments in which ciliary neuronotrophic activity was measured in the targets of chronically treated embryos, there was no difference between control and morphine-treated embryos (see Pilar et al., 1988b; H. J. L. Fryer and G. Pilar, unpublished observations).

Developing ciliary ganglion neurons, which are known to be dependent on the presence of the periphery (Levi-Montalcini and Amprino, 1947; Landmesser and Pilar, 1974b, 1978) and central synaptic connections (Levi-Montalcini, 1949; Furber et al., 1987), are also influenced by neuropeptides. Since most, if not all, of the endogenous opioids in the ciliary ganglion are present in the preganglionic central connections onto ciliary and choroid neurons, the increased neuronal death that occurs following central denervation may be partially due to the removal of the opioid peptides. Denervation of central connections onto the ganglion results in the near total degeneration (85-90\%) of the ciliary and choroid populations (Levi-Montalcini, 1949; Furber et al., 1987). Three daily applications of the opiate receptor blocker naltrexone only decreases ganglion cell survival by about $25 \%$. While it is not known if more frequent naltrexone applications would result in even more neuronal degeneration, it is unlikely that the endogenous opioids are the only factor supplied by central connections onto ganglion cells, and opioid peptides may act in concert with other preganglionic factors.

The regulation of neuronal survival is a complex process that probably involves the interplay of many peripheral, central, and possibly humoral factors. For example, primary sensory neurons appear to be sensitive to nerve growth factor from central as well as peripheral sources (see Johnson and Yip, 1985). It seems unlikely that cell survival in vivo depends on a single survival molecule. Recently, there have been several reports of the spe- cific action of local trophic factors on ciliary ganglion neuronal survival during devclopment. The generally accepted notion of the importance of CNTF as a target-derived neurotrophic factor is still in question. On one hand, Hendry et al. (1988) have observed immunoparasympathectomy in mice following treatment with a blocking monoclonal antibody to CNTF, but on the other hand, Oppenheim et al. (1991) were not able to show any increase in ciliary ganglion neuronal survival following mammalian CNTF application to the chicken embryo. This discrepancy could be due to the fact that chicken CNTF only has $57 \%$ homology with the mammalian CNTF (Lin et al., 1989; Eckenstein et al., 1990). It is likely that other growth factors, perhaps fibroblast growth factors (see Eckenstein et al., 1990), also play a role in this competition for survival. Our challenge is to identify the individual components and determine how they interact to regulate the final number of surviving neurons in a population.

\section{References}

Abercrombie M (1946) Estimation of nuclear population from microtome sections. Anat Rec 94:239-247.

Bardo MT, Bhatnager RK, Gebhart GF (1983) Age-related differences in the effect of chronic administration of naloxone on opiate binding in rat brain. Neuropharmacology 22:453-461.

Buckley K, Kelly RB (1985) Identification of a transmembrane glycoprotein specific for secretory vesicles of neural and endocrine cells. J Cell Biol 100:1284-1294.

Choi DW (1988) Calcium mediated neurotoxicity: relationship to specific channel types and role in ischemic damage. Trends Neurosci 11: $465-469$.

Collins F (1988) Role of voltage-activated calcium channels in the promotion of neuronal survival by potassium. Soc Neurosci Abstr 14:368.

Cowan WM, Fawcett JW, O'Leary DDM, Stanfield BB (1984) Regressive events in neurogenesis. Science 225:1258-1265.

D'Amato RJ, Blue ME, Largent BL, Lynch DR, Ledbetter DJ, Molliver ME, Snyder SH (1987) Ontogeny of the serotonergic projection to rat neocortex: transient expression of a dense innervation to primary sensory areas. Proc Natl Acad Sci USA 84:4322-4326.

Dryer SE, Chiappinelli VA (1985) Substance P depolarizes nerve terminals in an autonomic ganglion. Brain Res 336:190-194.

Eckenstein FP, Esch F, Holbert T, Blacher RW, Nishi R (1990) Purification and characterization of a trophic factor for embryonic peripheral neurons: comparison with fibroblast growth factors. Neuron 4:623-631.

Erichsen JT, Karten HJ, Eldred WD, Breca NC (1982) Localization of substance P-like and enkephalin-like immunoreactivity within preganglionic terminals of the avian ciliary ganglion: light and electron microscopy. J Neurosci 2:994-1003.

Furber S, Oppenheim RW, Prevette D (1987) Naturally-occurring neuron death in the ciliary ganglion of the chick embryo following removal of the preganglionic input: evidence for the role of afferents in ganglion cell survival. J Neurosci 7:1816-1832.

Gilman L, Rail T, Nies A, Taylor P, eds (1990) Goodman and Gilman's: the pharmacological basis of therapeutics, 8 th ed, p 516. New York: Pergamon.

Gray DB (1985) The effect of morphine on cell survival and ACh metabolism in the cultured avian ciliary ganglion. Soc Neurosci Abstr 11:175.

Gray DB, Ford MJ, Pilar G (1986) Differential opioid expression in cholincrgic ciliary ganglion neurons in vivo and in vitro. Soc Neurosci Abstr 12:1008.

Gray DB, Pilar G, Ford MJ (1989) Opiate and peptide inhibition of transmitter release in parasympathetic nerve terminals. J Neurosci 9 : 1683-1692.

Hamburger V, Hamilton HL (1951) A series of normal stages in the development of the chick embryo. J Morphol 88:49-92.

Handelmann GE (1985) Neuropeptide effects of brain development. J Physiol (Paris) 80:268-274.

Hauser KF, McLaughlin PJ, Zagon IS (1987) Endogenous opioids 
regulate dendritic growth and spine formation in developing rat brain. Brain Res 416:157-161.

Hauser KF, McLaughlin PJ, Zagon IS (1989) Endogenous opioid systems and the regulation of dendritic growth and spine formation. J Comp Neurol 281:13-22.

Haynes LW, Smith ME (1984) The actions of pro-opiomelanicortin peptides at the developing neuromuscular junction. Trends Pharmacol Sci 5:165-168.

Hendry IA, Hill CE, Belford D, Watters DJ (1988) A monoclonal antibody to a parasympathetic neurotrophic factor causes immunoparasympathectomy in mice. Brain Res 475:160-163.

Howlett TA, Rees LH (1986) Endogenous opioid peptides and hypothalamic-pituitary function. Annu Rev Physiol 48:527-536.

Johnson EM, Yip HK (1985) Central nervous system and peripheral nerve growth factor provide trophic support critical to mature sensory neuronal survival. Nature 314:751-752.

Katayama Y, Nishi S (1984) Sites and mechanism of actions of enkephalin in the feline parasympathetic ganglion. J Physiol (Lond) 351: 111-121.

Koike T, Martin DP, Johnson EM (1989) Role of $\mathrm{Ca}^{++}$channels in the ability of membrane depolarization to prevent neuronal death induced by trophic-factor deprivation: evidence that levels of internal $\mathrm{Ca}^{++}$determine nerve growth factor dependence of sympathetic ganglion cells. Proc Natl Acad Sci USA 86:6421-6425.

Landmesser L, Pilar G (1974a) Synaptic transmission and cell death during normal ganglionic development. J Physiol (Lond) 241:737749.

Landmesser L, Pilar G (1974b) Synapse formation during embryogenesis on ganglion cells lacking a periphery. J Physiol (Lond) 247: 715-736.

Landmesser L, Pilar G (1978) Interactions between neurons and their targets during in vivo synaptogenesis. Fed Proc 37:2016-2022.

Levi-Montalcini R (1949) The development of the acoustico-vestibular centers in the chick embryo in the absence of the afferent root fibers and of descending fiber tracts. J Comp Neurol 91:209-241.

Levi-Montalcini R, Amprino R (1947) Recherches experimentals sur l'origine du ganglion ciliare dans l'embryon de Poulet. Arch Biol 58: 265-288.

Lin L-FH, Mismer D, Lile JD, Armes LG, Butler ET, Vanice JL, Collins F (1989) Purification, cloning, and expression of ciliary neurotrophic factor (CNTF). Science 246:1023-1025.

Maderdrut JL, Reitzel JL, Okado N, Oppenheim RW (1985) Behavioral analysis of opiate-mediated inhibition in the early chick embryo. Neuroscience 16:405-416.

Margiotta JF, Berg DK (1986) Enkephalin and substance P modulate synaptic properties of chick ciliary ganglion neurons in cell culture. Neuroscience 18:175-182.

Martin WR (1983) Pharmacology of opioids. Pharmacol Rev 35:283323.

Marwitt R, Pilar G, Weakly JN (1971) Characterization of two ganglion cell populations in avian ciliary ganglia. Brain Res 25:317-334.

Meriney SD, Pilar G (1987) Cholinergic innervation of the smooth muscle cells in the choroid coat of the chick eye and its development. J Neurosci 7:3827-3839.

Meriney SD, Nunez R, Pilar G (1984) The effects of chronic neuromuscular blockade and cGMP administration on differential motoneuron survival in the avian ciliary ganglion. Soc Neurosci Abstr 10: 640 .

Meriney SD, Gray DB, Pilar G (1985) Morphine-induced delay of normal cell death in the avian ciliary ganglion. Science 228:14511453.

Meriney SD, Pilar G, Ogawa M, Nunez R (1987) Differential neuronal survival in the avian ciliary ganglion after chronic acetylcholine receptor blockade. J Neurosci 7:3840-3849.

Minneman KP, Iversen LL (1976) Enkephalin and opiate narcotics increase cyclic GMP accumulation in slices of rat neostriatum. Nature 262:313-314.

Nakanishi Y, Cuttitta F, Kasprzyk PG, Avis I, Steinberg SM, Gazdar AF, Mulshine JL (1988) Growth factor effects on small cell lung cancer cells using a colorimetric assay: can transferrin-like factor mediate autocrine growth? Exp Cell Biol 56:74-85.

Oppenheim RW, Prevette D, Yin QW, Collins F, McDonald J (1991) Control of embryonic motoneuron survival in vivo by ciliary neurotrophic factor. Science 251:1616-1618.

Parnavelas JG, Cavanagh ME (1988) Transient expression of neurotransmitters in the developing neocortex. Trends Neurosci 11:92-93.

Pilar G, Landmesser L (1976) Ultrastructural differences during embryonic cell death in normal and peripherally deprived ciliary ganglia. J Cell Biol 68:339-356.

Pilar G, Nunez R, McLennan IS, Meriney SD (1987) Muscarinic and nicotinic synaptic activation of the developing chicken iris. J Neurosci 7:3813-3826

Pilar G, Meriney SD, Gray DB (1988a) Trophic effects of muscle on nerve cell survival and development. In: Nerve-muscle cell trophic communication (Fernandez H, Donoso I, eds), pp 173-198. Boca Raton, FL: CRC

Pilar G, Fryer HJL, Meriney SD, Ford MJ (1988b) The regulation of neuronal number during embryonic chick development. Puerto Rico Health Sci J 7:149-155.

Pincus DW, DiCicco-Bloom EM, Black IB (1990) Vasoactive intestinal peptide regulates mitosis, differentiation and survival of cultured sympathetic neuroblasts. Nature 343:564-566.

Pittman R, Oppenheim RW (1978) Neuromuscular blockade increases motoneurone survival during normal cell death in the chick embryo. Nature 271:364-366.

Pittman R, Oppenheim RW (1979) Cell death of motoneurons in the chick embryo spinal cord. V. Evidence that a functional neuromuscular interaction is involved in the regulation of naturally-occurring cell death and stabilization of synapses. J Comp Neurol 187:425446.

Reiner A (1987) A VIP-like peptide co-occurs with substance $P$ and enkephalin in cholinergic preganglionic terminals of the avian ciliary ganglion. Neurosci Lett 78:22-28.

Role LW (1984) Substance P modulation of acetylcholine-induced currents in embryonic chicken sympathetic and ciliary ganglion neurons. Proc Natl Acad Sci USA 81:2924-2928.

Schmahl W, Funk R, Miaskowski U, Plendl J (1989) Long-lasting effects of naltrexone, an opioid antagonist, on cell proliferation in developing rat forebrain. Brain Res 486:297-300.

Schultz R, Wuster M, Herz A (1979) Supersensitivity to opioids following chronic blockade of endorphin activity by naloxone. Naunyn Schmiedebergs Arch Pharmacol 306:93-96.

Slesjo BK (1988) Historical overview. Calcium, ischemia, and death of brain cells. Ann NY Acad Sci 522:638-661.

Tuttle JB, Suszkiw J, Ard M (1980) Long term survival and development of dissociated parasympathetic neurons in culture. Brain Res 183:161-180.

Weill CL, Greene DP (1984) Prevention of natural motoneurone cell death by dibutyryl cyclic GMP. Nature 308:452-454.

White JD, Krause JE, Karten HJ, McKelvy JF (1985) Presence and ontogeny of enkephalin and substance $P$ in the chick ciliary ganglion. J Neurochem 45:1319-1322.

Wright LL (1981) Cell survival in the chick embryo ciliary ganglion is reduced by chronic ganglionic blockade. Dev Brain Res 1:283-286.

Zachary I, Penella W, Rosengurt E (1987) A role for neuropeptides in the control of cell proliferation. Dev Biol 124:295-308.

7agon IS, McLaughlin PJ (1984) Naltrexone modulates body and brain development in rats: a role for endogenous opioids in growth. Life Sci 35:2057-2064.

Zagon IS, McLaughlin PJ (1986) Opioid antagonist (naltrexonc) modulation of cerebellar development: histological and morphometric studies. J Neurosci 6:1424-1432.

Zagon IS, McLaughlin PJ (1987) Endogenous opioid systems regulate cell proliferation in the developing rat brain. Brain Res 412:68-72.

Zukin RS, Sugarman JR, Fitz-Syage ML, Gardner EL, Zukin SR, Gintzler AR (1982) Naltrexone-induced opiate receptor supersensitivity. Brain Res 245:285-292. 